\title{
ANALISIS DAN PENGEMBANGAN SISTEM MANAJEMEN PENGETAHUAN BERBASIS PERANGKAT LUNAK OPEN SOURCE (STUDI KASUS)
}

\author{
Yohannes Kurniawan, Ogi Sarwengga,Taufiq Febri Dewanto, Wisnu Try Hantoro \\ Bina Nusantara University \\ Jl. KH Syahdan No. 9, Kemanggisan, Jakarta Barat, 11480, Indonesia \\ Email: kurniawan_yohannes@yahoo.com
}

\begin{abstract}
Abstrak
Penelitian ini akan memaparkan proses identifikasi dan kategorisasi pengetahuan yang di miliki oleh PT XYZ sebagai objek penelitian, dimana perusahaan ini membutuhkan wadah yang mendukung sharing knowledge untuk pendokumentasian dan pendistribusian pengetahuan yang ada pada perusahaan tersebut, serta menerapkan sistem open source untuk mengelola pengetahuan secara mandiri dan terpusat. Metode penelitian yang dilakukan adalah dengan Inukshuk KM Model. Metode pengumpulan data yang digunakan adalah wawancara dan observasi. Hasil yang dicapai dari penelitian ini adalah tersedianya wadah untuk menyimpan dan mengelola pengetahuan yang mudah diakses oleh pengguna. Dengan pengimplementasian sistem manajemen pengetahuan ini diharapkan dapat meningkatan kualitas sharing knowledge antar karyawan, serta meningkatan kualitas knowledge content yang terdapat didalam perusahaan.
\end{abstract}

Kata kunci: Analisis, Pengembangan, Manajemen Pengetahuan

\begin{abstract}
This study will describe the process of identification and categorization of knowledge in $P T X Y Z$ as the research object, where the company requires a container that supports the sharing of information for documentation and dissemination of existing knowledge in the company, as well as implementing an open source system for managing knowledge independently and centralized. The research method is Inukshuk KM Model and data collection methods used were interviews and observation. The outcome of this research is a receptacle for storing and managing knowledge that is easily accessible by the user. With the implementation of knowledge management system is expected to improve the quality of knowledge sharing among employees, as well as improving the quality of knowledge content in the company.
\end{abstract}

Keywords: Analysis, development, Knowledge Management

\section{PENDAHULUAN}

Sumber daya pengetahuan merupakan sumber daya penting bagi organisasi. Organisasi sangat menyadari bahwa pengetahuan perlu dikeloka dengan baik agar dapat menjadikan 
organisasi menjadi lebih baik lagi dalam melakukan pengambilan keputusan. Bahkan pengetahuan ini harus dikelola dengan baik agar dapat menghasilkan inovasi bagi organisasi. Tentunya pengelolaan pengetahuan ini tidak dapat dilakukan dengan cara manual, organisasi memerlukan sistem informasi untuk dapat memudahkan mengelola pengetahuan dengan lebih terstruktur dan sistematis.

Dimana pada penelitian ini akan membahas studi kasus kebutuhan sistem informasi untuk mendukung pengelolaan pengetahuan pada peruasahaan, dimana pada PT XYZ (nama disamarkan) adalah perusahaan infrastruktur teknologi yang berada di Jakarta. Perusahaan ini bergerak di dunia teknologi informasi dan komunikasi, yaitu penyedia solusi storage, server dengan partner perusahaan terkemuka. Perusahaan ini memiliki customer berjumlah 60 dan jumlah karyawan keseluruhan pada saat ini 86 orang. Selama ini para karyawan PT XYZ mengalami kesulitan di dalam melakukan sharing knowledge. Salah satunya adalah dalam menjalankan proses bisnis setiap harinya, misalnya jika terjadi perubahan konfigurasi pada customer dimana sistem di implementasikan oleh engineer berbeda. Biasanya informasi atau pengetahuan yang dibutuhkan oleh engineer lain, pendistribusian hanya melalui email atau telepon sebagai sarananya. Dengan banyaknya customer dan engineer yang memegang data customer berbeda-beda mengakibatkan konfigurasi sistem yang terbaru tidak di sebarluaskan secara merata, dan hal ini berdampak pada pengaksesan dan pengelolaan pengetahuan yang dibutuhkan memakan waktu lama dan kurang maksimal. Akibatnya sering terjadi salah komunikasi antar divisi dan antar karyawan yang pada akhirnya akan dapat menghambat pengambilan keputusan dan jalannya bisnis di perusahaan. Ditambah lagi apabila perusahaan menghadapi kasus pengunduran diri dari karyawan yang memiliki knowledge menonjol, sementara pada saat itu belum ada transfer knowledge bagi penggantinya.

Berdasarkan permasalahan tersebut ditambah keterbatasan budgeting untuk mengembangankan knowledge management dan melimpahnya resource hardware di perusahaan seperti storage maupun server, maka kami tertarik untuk melakukan penelitian ini. Diharapkan dengan mengelola intelektual sumber daya manusia ini pada PT XYZ yang saat ini memiliki banyak pengetahuan, baik dalam bentuk dokumen maupun pengetahuan yang baru berupa ide atau pemikiran, dapat digunakan lebih baik dalam meningkatkan kinerja dan mendukung perusahaan dalam pengambilan keputusan karena semua pengetahuan ini merupakan sebuah aset penting bagi perusahaan.

\section{PENELITIAN TERKAIT}

Dalam konteks terkait dengan sistem dan teknologi informasi, pengetahuan berbeda dengan data dan informasi. Pengetahuan adalah informasi yang berhubungan dengan konteks, relevan, dan berguna. Pengetahuan lebih banyak dikaitkan dengan informasi dalam tindakan yang berarti lebih berkaitan dengan keahlian dan pengalaman seseorang. Sering kali pengetahuan dikaitkan juga dengan asset intelektual [6].

Oleh karena itu sistem informasi yang dibangun oleh organisasi harus berfokus pada pengelolaan pengetahuan bukanlah informasi ataupun data yang ada pada organisasi tersebut. Karena sering kali organisasi membangun sistem manajemen pengetahuan yang hanya berfokus pada pengelolaan informasi, bukan pada pengelolaan pengetahuan.

Berdasarkan Polanyi yang dikutip dari [2], jenis-jenis pengetahuan ada dua, yaitu pengetahuan tacit dan juga pengetahuan eksplisit. Dimana pada konteks studi kasus ini pengelolaan pengetahuan difokuskan pada pengetahuan eksplisit, bukan pengetahuan tacit dari setiap individu karyawan yang ada pada organisasi. 
Sistem manajemen pengetahuan yang dibangun pada organisasi ini difokuskan untuk menangkap (knowledge capture) dan mendistribusikan pengetahuan antar pekerja pengetahuan yang ada pada organisasi sejalan dengan yang didefinisikan oleh [7], manajemen pengetahuan bertujuan untuk menangkap dan mendistribusikan pengetahuan pada organisasi melalui dukungan dari teknologi informasi dan komunikasi sehingga pengetahuan tersebut dapat dengan mudah dan cepat dibagikan.

Manajemen pengetahuan secara langsung berhubungan dengan proses pembelajaran organisasi yang berkaitan dengan kegiatan ekplorasi dan juga berbagi pengetahuan dengan dukungan teknologi yang tepat serta dukungan dari budaya organisasi akan dapat meningkatkan aset intelektual pada organisasi [4]

Maka dapat disimpulkan bahwa sistem manajemen pengetahuan pada dasarnya hanya sebuah alat yang digunakan membantu mengumpulkan pengetahuan sebagai repository dan membantu untuk mendistribusikannya dengan tentunya diperlukan dukungan organisasi untuk meyakinkan yang dikelola pada organisasi adalah pengetahuan dan bukannnya hanya data atau informasi.

Pengetahuan merupakan aset intelektual yang dimiliki baik oleh organisasi maupun individual yang berada pada organisasi tersebut [3]. Jika manajemen pengetahuan dilakukan oleh organisasi dengan baik, maka akan dapat meningkatkan kualitas pengetahuan yang ada pada setiap individu yang ada pada organisasi tersebut yang pada akhirnya akan meningkatkan keuntungan bagi organisasi melalui terciptanya inovasi-inovasi baru yang dihasilkan oleh setiap individu yang ada pada organisasi.

Menurut [1], manajemen pengetahuan dapat memberikan bermanfaat untuk: People, Process, Products dan juga organizational performance. Untuk dapat meningkatkan kualitas pengetahuan yang ada pada organisasi, maka organisasi membutuhkan proses pengelolaan pengetahuan dengan baik, khususnya berkaitan dengan proses transfer pengetahuan antar setiap personil yang ada dalam organisasi [5].

\section{METODE PENELITIAN}

Metode yang digunakan dalam penelitian ini dibagi menjadi dua, metode pengumpulan data dilakukan dengan mengumpulkan data melalui wawancara kepada pimpinan perusahaan tersebut untuk mendapat kebutuhan utama dari pengelolaan pengetahuan tersebut. Setelah mendapatkan hasil wawancara tersebut selanjutnya penulis melakukan wawancara kepada pekerja pengetahuan yang ada pada perusahaan dan observasi langsung pada perusahaan yang berlangsung selama 3 bulan untuk mendapatkan detil kebutuhan sistem informasi tersebut. Sedangkan metode knowledge management model pada penelitian ini mengadopsi metode Inukshuk Knowledge Management Model [2], dimana model knowledge management ini merupakan metode penyempurnaan dari SECI Model yang dipopulerkan oleh Nonaka dan Takeuchi. Pada Inukshuk Knowledge Management Model bukan hanya befokus pada konversi pengetahuan tetapi juga menekankan pada aspek kepemimpinan, teknologi dan juga budaya seperti terlihat pada gambar dibawah ini. 


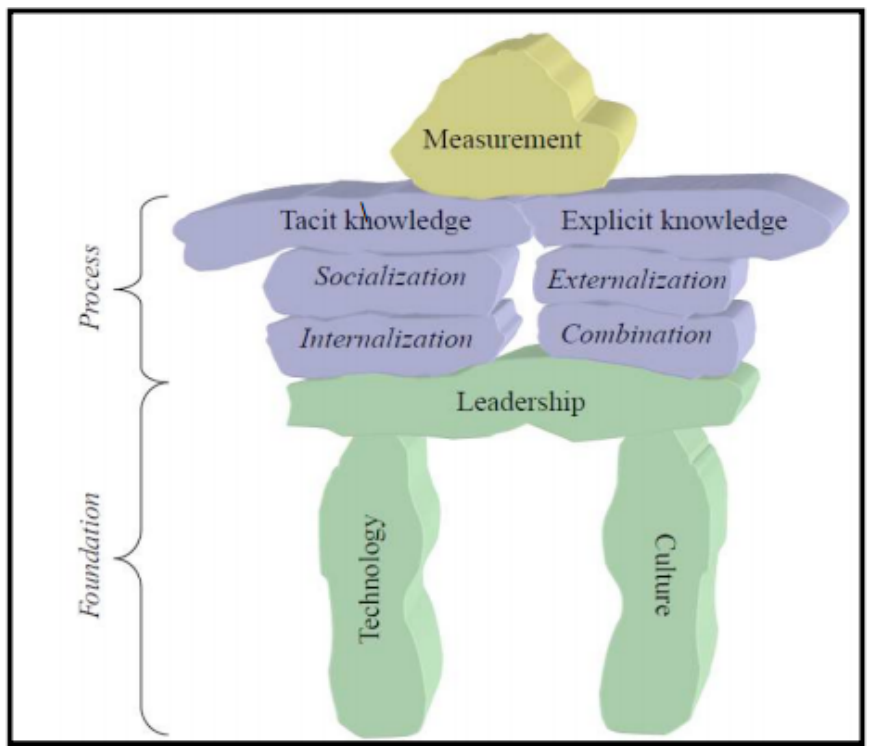

Gambar. 1. Inukshuk Knowledge Management Model, Sumber: (Dalkir, 2011)

\section{HASIL DAN PEMBAHASAN}

Berdasarkan analisis persamasalahan yang diperoleh melalui wawancara yang terdapat pada perusahaan didapatkan beberapa permasalahan, Masalah yang dihadapi oleh PT XYZ adalah pengetahuan yang diterima masing-masing divisi yang dijabarkan pada proses bisnis berjalan diatas masih dipegang secara perorangan dan belum terdistribusi secara terpusat. Akibatnya adalah:

a) Dokumen project sales ke engineer kurang terdistribusi dengan baik, akibatnya sering sekali terjadi missed communication antar engineer ke customer prihal support dan maintenance customer tersebut.

b) Dokumen instalasi project consultant ke engineer kurang terdistribusi dengan baik, sebagai contoh akibatnya ketika ada project upgrade yang berada di customer A, consultant masih mencari konfigurasi terakhir customer A ke divisi engineer yang memegang dokumen instalasi project tersebut.

c) Dokumen instalasi project engineer ke engineer kurang terdistribusi dengan baik akibatnya sesama engineer masih bertanya via grup atau ke personal engineer, hal ini mengakibatkan proses pencarian pengetahuan akan memakan waktu lebih lama.

d) Ketika ada project yang membutuhkan requirement dan skill engineer tertentu, bagian sales tidak mempunyai informasi lengkap terkait dengan sumber daya engineer ter-update, sehingga bagian sales harus menghubungi divisi sumber daya manusia dahulu atau menanyakan satu persatu ke engineer yang memenuhi skill tersebut.

e) Masalah lain yang muncul adalah ketika ada salah satu engineer yang resign atau berhalangan hadir, sehingga data yang diinginkan tidak ada pada saat di butuhkan.

Selain identifikasi permasalahan melalui proses wawancara tersebut, berdasarkan hasil observasi dan wawancara penulis juga melakukan identifikasi pengetahuan perusahaan dengan menggunakan tools knowledge taxomomy seperti terlihat di bawah ini. 


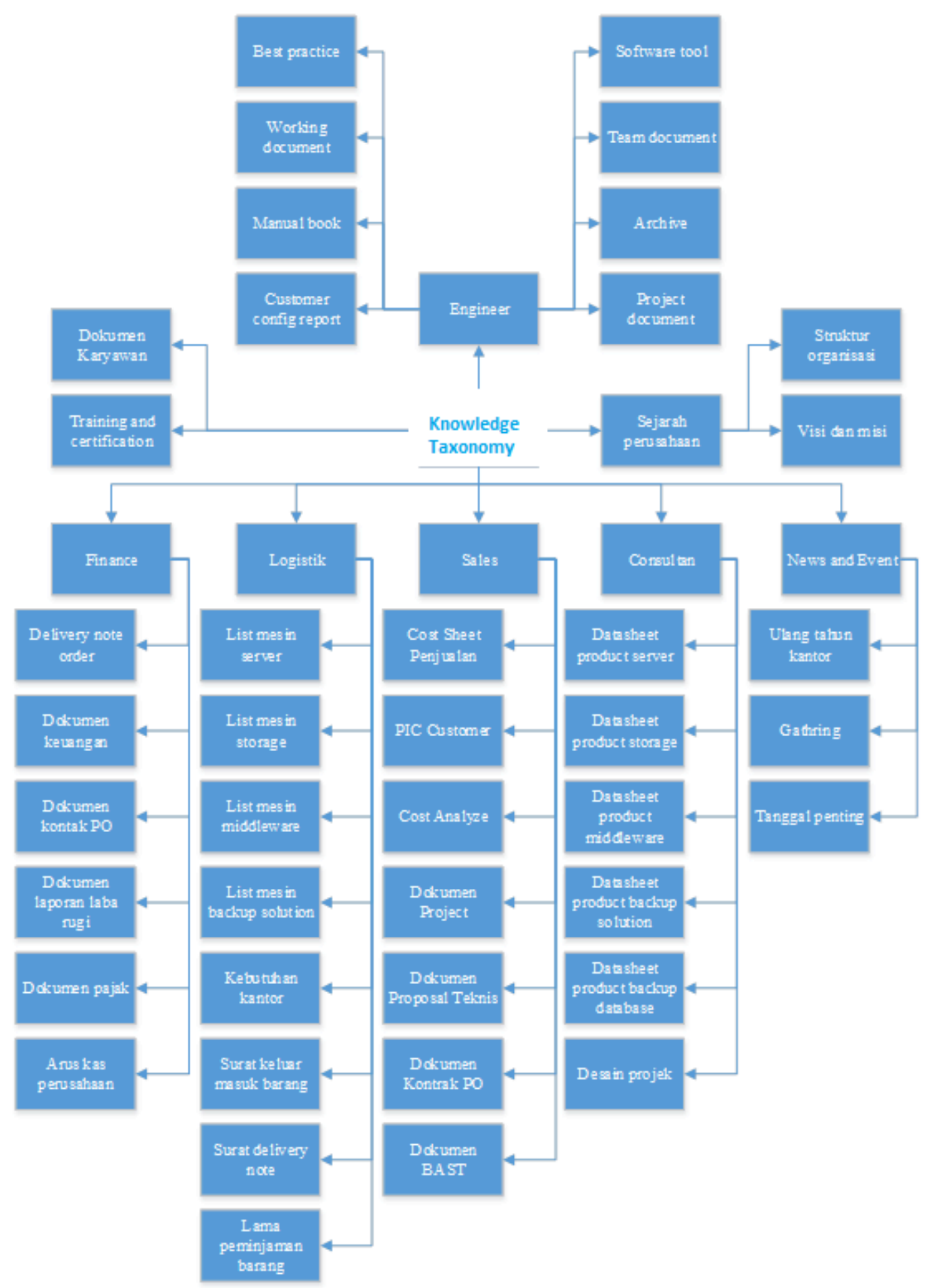

Gambar. 2. Taksonomi Pengetahuan

Analisis taksonomi pengetahuan ini berguna untuk mengidentifikasi semua pengetahuan penting di perusahaan yang seharusnya dapat disimpan dengan sistem manajemen pengetahuan.

\subsection{Peran Kepemimpinan} adalah :

Peran pemimpin dengan dibangunnya sistem manajemen pengetahuan pada PT XYZ 
a. Mengelola dokumen dan pengetahuan yang menjadi tanggung jawab dari knowledge leader (mengubah dan menghapus).

b. Leader akan mengarahkan dan mengontrol staf bawahannya untuk meningkatkan knowledge perorangan maupun tim, untuk itu knowledge dibagi menjadi dua jenis:

1. Private folder, didalamnya berisi tuangan ide dari perorangan yang mempengaruhi nilai staf secara perorangan, nilai tersebut diperoleh berdasarkan apakah ide yang dituangkan staf tersebut layak atau tidak menurut leader. Layak atau tidaknya ide tersebut akan dibahas saat rapat bulanan. Dengan dibahasnya ide tersebut dalam rapat bulanan, maka leader akan dapat melihat dan membuat daftar kelayakan serta kualitas dari stafnya, dan nilai ini akan diakumulasikan oleh leader tersebut setelah 1 tahun. Daftar kelayakan serta kualitas pengetahuan dari stafnya yang didapatkan leader pada saat meeting bulanan akan berpengaruh pada persentasi kenaikan gaji staf tersebut ketika nanti diakumulasi selama 1 tahun.

2. Team folder, didalamnya berisi kinerja tim yang mana setiap ada pengetahuan yang di-upload dan di-share ataupun diperbaiki oleh staf adalah untuk tim. Yang artinya staf akan sebaik mungkin dalam membuat aset intelektual tim yang di share tersebut. Sama halnya dengan private folder, team folder akan dibahas dalam rapat bulanan untuk melihat proyek yang dikerjakan tim, apakah memang pantas dijadikan aset intelektual perusahaan, atau yang sebelumnya terdapat kesalahan bisa diperbaiki sehingga menjadi aset intelektual.

Ketika tanggung jawab yang dilakukan oleh leader sesuai dengan yang diharapkan oleh direksi dan asset pengetahuan yang dimiliki oleh perusahaan meningkat, maka nantinya akan berpengaruh pada persentasi kenaikan gaji dari knowledge leader tersebut.

\subsection{Peran Budaya Organisasi}

Budaya yang kami sarankan adalah memberikan kesadaran kepada setiap individu dalam penerapan sistem manajemen dengan memberikan beberapa aspek penilaian yang mencakup: motivasi untuk berbagi pengetahuan, komunikasi dan kerjasama, dan juga pengembangan diri.

\subsection{Peran Teknologi Informasi}

Teknologi yang penulis sarankan dalam penerapan manajemen pengetahuan untuk perusahaan ini adalah Network Attached Storage (NAS). Perangkat penyimpanan yang terpasang ke Jaringan adalah perangkat penyimpanan yang tersambung ke jaringan yang memungkinkan penyimpanan dan pengambilan data dari lokasi terpusat untuk pengguna jaringan dan klien heterogen yang sah. Perangkat NAS fleksibel dan scale-out, maksudnya adalah saat anda memerlukan penyimpanan tambahan, dapat menambahkannya ke perangkat yang anda miliki.

NAS adalah sistem yang berdiri sendiri, penyimpanan pengetahuan dapat dibagi secara langsung ke dalam jaringan dan dapat diakses ke dalam server yang beraneka ragam dan juga komputer klien (seperti, Unix, Windows NT/2000, Netware, Linux, dll.). Aplikasi NAS penting untuk mengoptimalkan pembagian file ke dalam jaringan. Dengan cara yang sederhana dilakukan dengan hanya menempelkan alat tersebut ke dalam jaringan, bagian IT dapat dengan cepat dan mudah mengembangkan kapasitas jaringan peyimpanan. Solusi sistem manajemen pengetahuan yang digunakan untuk studi kasus perusahaan ini adalah FreeNAS. Pada tabel dibawah ini menjelaskan kelebihan dan kekurangan FreeNAS yang menjadi bahan pertimbangan penggunaan perangkat lunak ini. 
Computatio: Journal of Computer Science and Information Systems

Volume 1 Tahun 2017

Tabel 1. Kelebihan dan Kekurangan FreeNAS

\begin{tabular}{|c|c|}
\hline \multicolumn{2}{|c|}{ FreeNAS } \\
\hline Kelebihan & Kekurangan \\
\hline $\begin{array}{ll}\text { - } & \text { Support ZFS \& enkripsi } \\
\text { - } & \text { Spesifikasi hardware bisa } \\
\text { dirakit atau bisa beli server } \\
\text { langsung tergantung budget dan } \\
\text { kebutuhan } \\
\text { - } \quad \text { Mempunyai user interface } \\
\text { berbasiskan web yang mudah } \\
\text { - } & \text { Proses update otomatis }\end{array}$ & 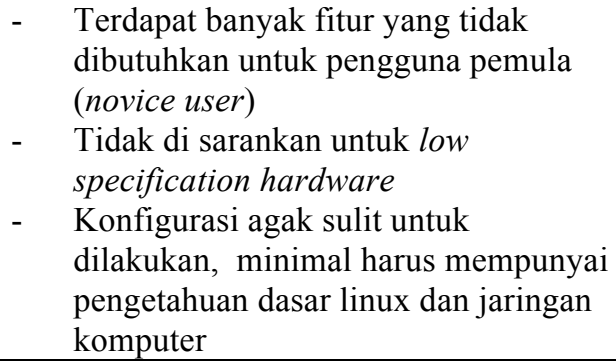 \\
\hline
\end{tabular}

Spesifikasi perangkat lunak yang dibutuhkan server production untuk instalasi sistem dan perangkat lunak client untuk mengakses system (baik menggunakan personal komputer atau mobile phone) dapat dilihat pada tablel di bawah ini.

Tabel 2. Software Specification

\begin{tabular}{|l|l|l|}
\hline No & Software & Specification \\
\hline 1 & Server & Freenas Version \\
\hline 2 & PC Client & $\begin{array}{l}\text { a) Sistem operasi yang mendukung web browser } \\
\text { b) Web browser safari, google chrome, mozilla firefox, atau } \\
\text { microsoft edge }\end{array}$ \\
\hline 3 & $\begin{array}{l}\text { Mobile } \\
\text { Client }\end{array}$ & $\begin{array}{l}\text { a) Sistem operasi mobile yang mendukung web mobile } \\
\text { browser } \\
\text { b) Web mobile browser }\end{array}$ \\
\hline
\end{tabular}

Pada gambar dibawah ini menggambarkan proses manajemen pengetahuan dalam empat dimensi SECI Model sesuai dengan teori dari Nonaka dan Takeuchi yang memetakan fitur-fitur sistem manajemen pengetahuan dalam empat proses, yaitu socialization, externalization, combination dan internalization yang menggambarkan knowledge conversion process untuk mendukung peningkatan jumlah pengetahuan eksplisit pada organisasi.

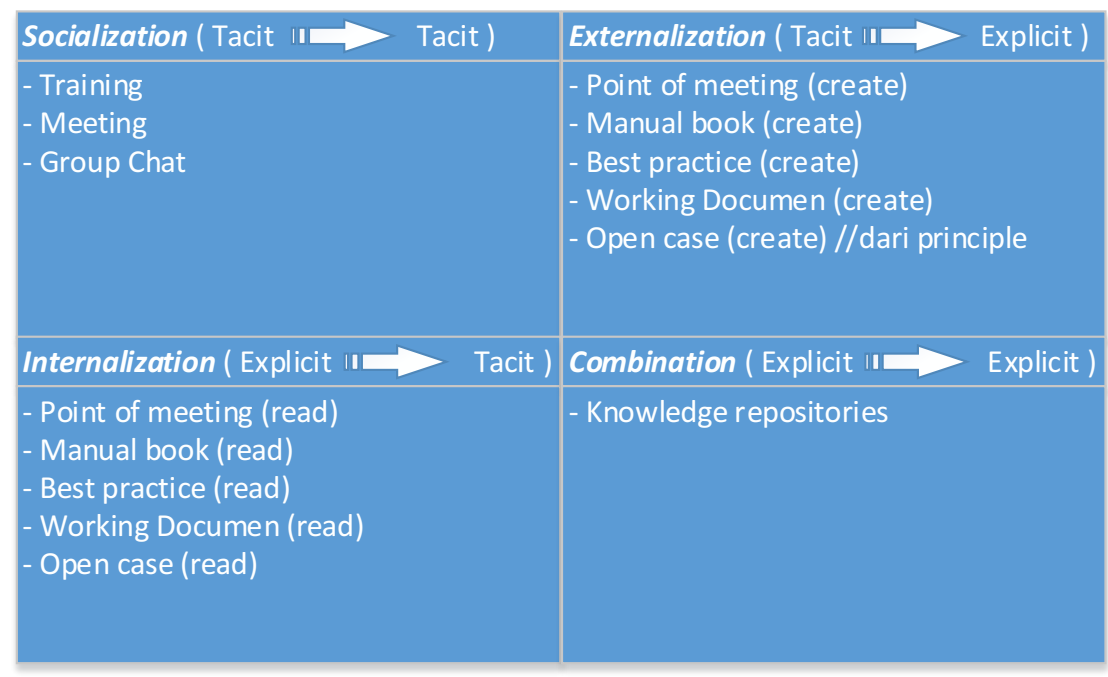

Gambar. 3. Pemetaan SECI usulan 
Use case diagram dibawah ini menggambarkan sistem FreeNAS untuk mengelola user yang akan digunakan oleh admin untuk mengelola semua pengguna yang terdaftar pada sistem. Admin dapat menambahkan pengguna, mengubah data pengguna, menghapus pengguna, dan melihat semua daftar pengguna yang ada pada sistem.

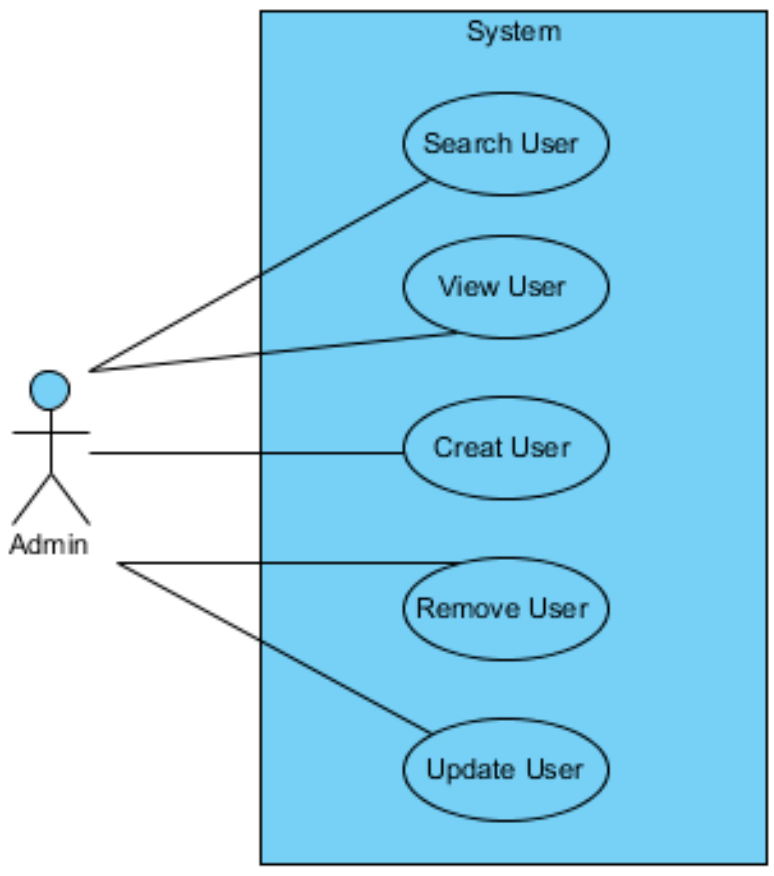

Gambar. 4. Use case diagram Untuk mengelola user

Sedangkan use case diagram untuk fungsi knowledge repository dibagi menjadi lima bagian besar, yaitu mencari knowledge, akses seluruh knowledge, kelola knowledge yang menjadi tanggung jawab, mengelola point of meeting, dan akses cepat dapat dilihat pada gambar dibawah ini.

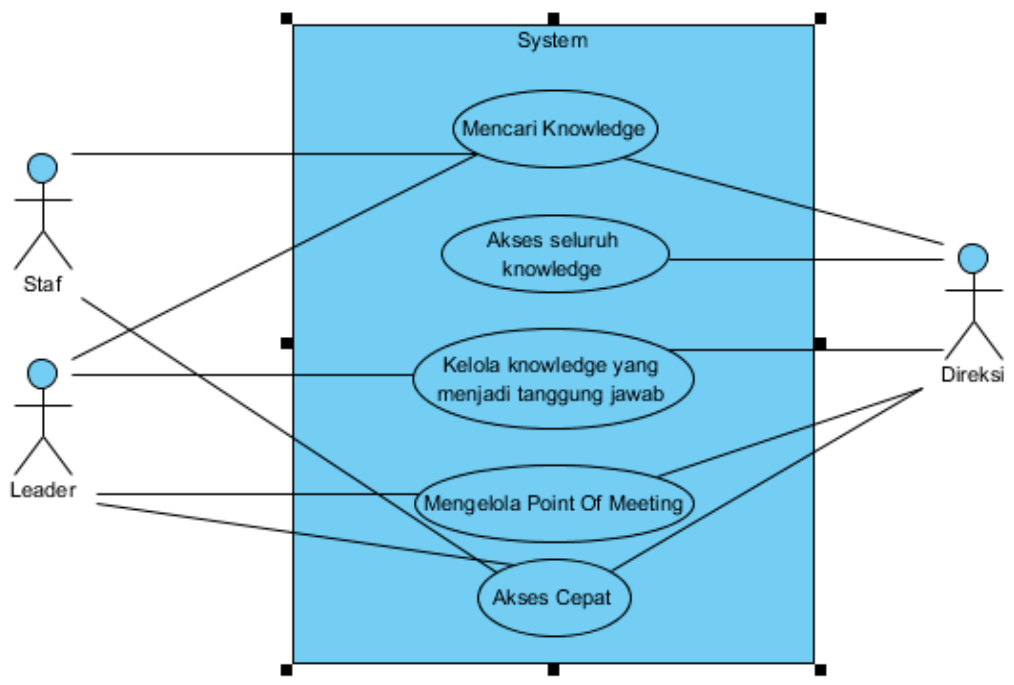

Gambar. 5. Use case diagram Untuk Knowledge Repository 
Berikut salah satu contoh dari user interface dari aplikasi FeeNAS yang digunakan pada organisasi ini.

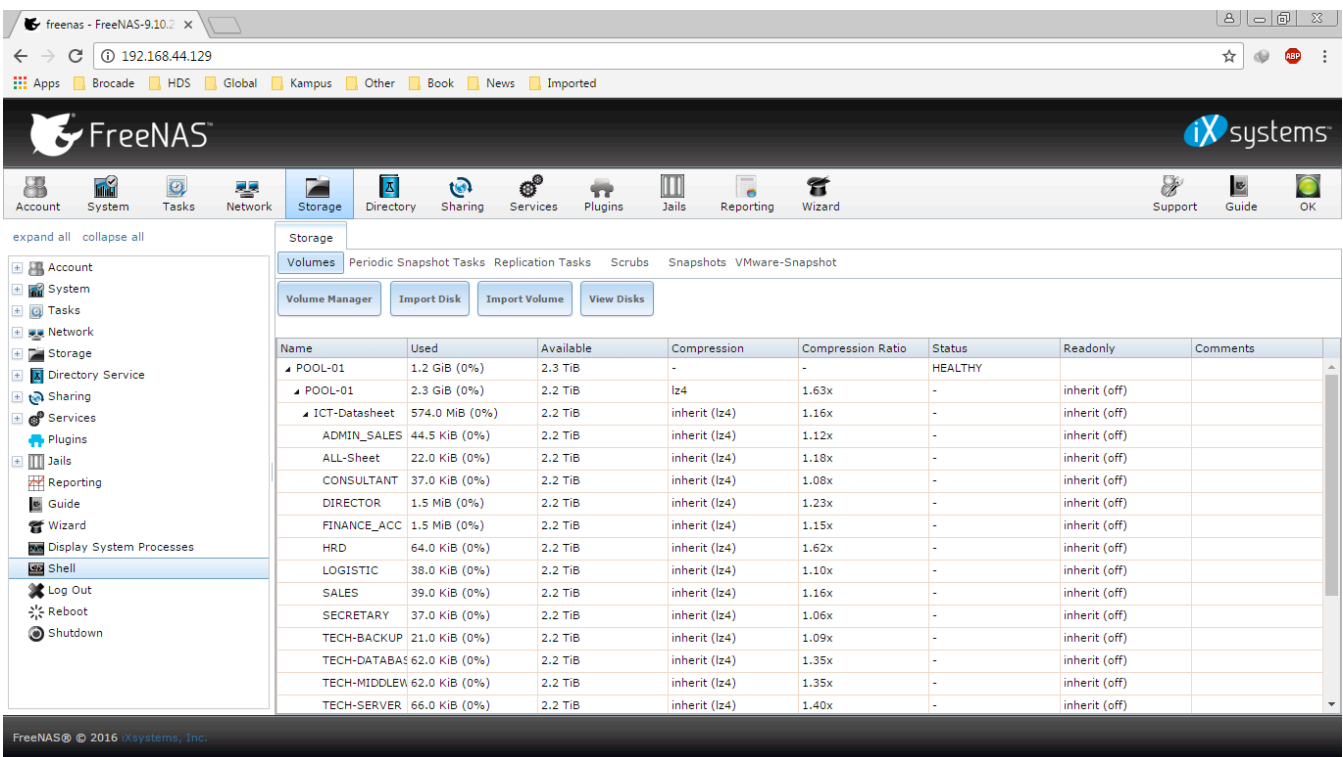

Gambar 6. User Interface untuk Storage Administration

Pada saat pengimplementasian sistem manajemen pengetahuan perlu juga dianalisis terkait dengan akses privilege dari setiap bagian yang ada pada organisasi, sebagai contoh berikut rule yang akan di terapkan pada system FreeNAS di divisi FINANCE_ACC.

Tabel 3. Rule User Permission pada folder FINANCE_ACC

\begin{tabular}{|c|c|c|c|c|c|}
\hline Division & Folder & Subfolder 1 & Subfolder 2 & Access & Permit \\
\hline \multirow{31}{*}{ FINANCE_ACC } & \multirow{4}{*}{ Delivery Note Order } & \multirow{4}{*}{ Customer } & \multirow{4}{*}{ Tahun } & Root & \multirow{2}{*}{ Full Control } \\
\hline & & & & Director & \\
\hline & & & & ICT-FINANCE_ACC & Special \\
\hline & & & & Everyone & Read and Execute \\
\hline & \multirow{3}{*}{ Dokumen Keuangan } & \multirow{3}{*}{ Tahun } & \multirow{3}{*}{ Bulan } & Root & \multirow{2}{*}{ Full Control } \\
\hline & & & & Director & \\
\hline & & & & ICT-FINANCE_ACC & Special \\
\hline & \multirow{4}{*}{ Dokumen Kontrak PO } & \multirow{4}{*}{ Tahun } & \multirow{4}{*}{ Customer } & Root & \multirow{2}{*}{ Full Control } \\
\hline & & & & Director & \\
\hline & & & & ICT-FINANCE ACC & Special \\
\hline & & & & Everyone & Read and Execute \\
\hline & \multirow{3}{*}{$\begin{array}{c}\text { Dokumen Laporan Laba } \\
\text { Rugi }\end{array}$} & \multirow{3}{*}{ Tahun } & \multirow{3}{*}{ - } & Root & \multirow{2}{*}{ Full Control } \\
\hline & & & & Director & \\
\hline & & & & ICT-FINANCE_ACC & Special \\
\hline & \multirow{3}{*}{ Dokumen Pajak } & \multirow{3}{*}{ Tahun } & \multirow{3}{*}{-} & Root & \multirow{2}{*}{ Full Control } \\
\hline & & & & Director & \\
\hline & & & & ICT-FINANCE_ACC & Special \\
\hline & \multirow{3}{*}{ Arus Kas Perusahaan } & \multirow{3}{*}{ Tahun } & \multirow{3}{*}{ Bulan } & Root & \multirow{2}{*}{ Full Control } \\
\hline & & & & Director & \\
\hline & & & & ICT-FINANCE_ACC & Special \\
\hline & \multirow{8}{*}{ _Knowledge Individu } & \multirow{4}{*}{ Nama Karyawan 1} & \multirow{4}{*}{ - } & Owner & \multirow{3}{*}{ Full Control } \\
\hline & & & & Root & \\
\hline & & & & Director & \\
\hline & & & & Everyone & Read Only \\
\hline & & \multirow{4}{*}{ Nama Karyawan 2} & & Owner & \\
\hline & & & 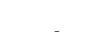 & Root & Full Control \\
\hline & & & & Director & \\
\hline & & & & Everyone & Read Only \\
\hline & & & & Root & Foll Control \\
\hline & Point of Meeting & Tahun & & Director & rull Control \\
\hline & & & & ICT-FINANCE ACC & Special \\
\hline
\end{tabular}

Note :
\begin{tabular}{|c|c|}
\hline Full Control & All Access \\
\hline \multirow{4}{*}{ Special } & Read Folder and File \\
\cline { 2 - 2 } & Write folder and file \\
\cline { 2 - 2 } & Execute Folder and file \\
\cline { 2 - 2 } & Modify Folder and File \\
\hline \multirow{2}{*}{ Read and Execute } & Read Folder and File \\
\cline { 2 - 2 } & Execute Folder and file \\
\hline & \multicolumn{2}{|c|}{ Privte Folder } \\
\hline & Share Folder \\
\hline
\end{tabular}




\section{KESIMPULAN}

Berdasarkan hasil analisis sistem manajemen pengetahuan yang telah dilakukan, maka dapat diambil kesimpulan sebagai berikut :

1. PT XYZ memiliki banyak pengetahuan seperti dokumentasi hasil pengerjaan suatu proyek, manual book, best practice, person in charge dari customer, desain proyek, datasheet setiap produk, dokumen teknis, dokumen selama pengerjaan, dan ide-ide karyawan. Masalahnya saat ini adalah sebagian besar dari pengetahuan yang ada tidak tersimpan dengan baik, bahkan beberapa diantaranya tidak diperhatikan dengan baik. Dengan analisis sistem manajemen pengetahuan maka pengetahuan pada organisasi dapat didentifikasikan dan dikategorisasasi sehingga diharapkan dapat menyimpan serta mengekfektifkan distribusi dari pengetahuan tersebut dan akan dapat berdampak pada meningkatnya kinerja perusahaan.

2. Sistem manajemen pengetahuan dengan menggunakan FreeNas sebagai knowledge repository yang terpusat dan mudah dikontrol pada perusahaan menjadi solusi dalam keterbatasan budget perusahaan sekaligus dapat memanfaatkan sumber daya yang tersedia di perusahaan saat ini, sehingga proses bisnis perusahaan dengan pemanfaatan pengetahuan menjadi lebih maksimal melalui kecepatan dan ketepatan dalam pengaksesan pengetahuan yang tersedia melalui pemanfaaatan fitur-fitur freeNAS seperti replikasi, enkripsi, snapshots dan file sharing.

3. Diharapkan penelitian ini dapat menjadi referensi bagi penelitian selanjutnya, khususnya terkait dengan penerapan sistem manajemen pengetahuan melalui perangakat lunak opensource.

\section{DAFTAR PUSTAKA}

[1] Bacerra-Fernandez, I., \& Sabherwarl, R. (2010). Knowledge Management Systems and Processes. New York: M. E. Sharpe, Inc.

[2] Dalkir, K. (2011). Knowledge Management in Theory and Practice (Second ed.). United States: Massachusetts Institute of Technology.

[3] Harkat, C. Z. (2011). Technology Options To Support The Implementation Of Knowledge. International Journal of Communication \& Information Technology, 74-81.

[4] Jashapara, A. (2011). Knowledge Management An Integrated Approach (Second ed.). England: Pearson Education Limited.

[5] Mathew, V. (2011). KM Strategies (Part 1): Key To Change And Development In Business. Journal of Knowledge Management Practice, Vol. 12, No. 1, 3-4. Retrieved from http://www.tlainc.com/articl252.htm.

[6] Rainer, R. K., Prince, B., \& Watson, H. J. (2015). Management Information Systems, 3rd Edition. John Wiley \& Sons.

[7] Vo, L.C. (2012). International Business Research. Pragmatist Perspective on Knowledge and Knowledge Management in organizations, 78-88. 